九州大学学術情報リポジトリ

Kyushu University Institutional Repository

\title{
Assessment of Hardness on AA2014/Eggshell Composite Produced Via Electromagnetic Stir casting Method
}

Shashi Prakash Dwivedi

G. L. Bajaj Institute of Technology \& Management

Nagendra Kumar Maurya

G. L. Bajaj Institute of Technology \& Management

Manish Maurya

Accurate Institute of Management and Technology

https://doi.org/10.5109/2547354

出版情報 : Evergreen. 6 (4)，pp. 285-294，2019-12. 九州大学グリーンテクノロジー研究教育センター バージョン：

権利関係 : 


\title{
Assessment of Hardness on AA2014/Eggshell Composite Produced Via Electromagnetic Stir casting Method
}

\author{
Shashi Prakash Dwivedi*1, Nagendra Kumar Maurya ${ }^{1}$, Manish Maurya ${ }^{2}$ \\ ${ }^{1}$ G. L. Bajaj Institute of Technology \& Management, Greater Noida, Gautam Buddha Nagar, U.P. 201306, \\ India \\ ${ }^{2}$ Accurate Institute of Management and Technology, Greater Noida, Gautam Buddha Nagar, U.P. 201310, \\ India
}

E-mail:*spdglb@gmail.com

(Received Jun 25, 2019; Revised September 26, 2019; accepted September 30, 2019).

\begin{abstract}
Present investigation agreements with the influence of reinforcement on hardness properties of eggshell reinforced AA2014 composite material. Aluminium based composite materials reinforced with eggshell were prepared by electromagnetic stir casting technique (EMS). Experiments were conducted by using Response Surface Methodology (RSM). Uncarbonized eggshell weight percentage, stirring time, matrix pouring temperature, preheat temperature, and stirring current were the selected process parameters. The maximum hardness of AA 2014/eggshell composite are achieved $86.4865 \mathrm{BHN}$ at optimum levels of process parameters i.e. reinforcement weight percentage of $12.5 \%$, preheat temperature of $600^{\circ} \mathrm{C}$, stir time of 3 minutes, matrix pouring temperature at $700{ }^{\circ} \mathrm{C}$, and stirring current of $12 \mathrm{~A}$. Results depicted that uncarbonized eggshell content in AA 2014 alloy had improved the hardness. Confirmation experiment was conducted to verify the result of hardness. It was observed that at optimum level of stir casting method parameter, tensile Strength was also improved. Owing to strengthening of uncarbonized eggshell in AA 2014 alloy, hardness and tensile strength properties was improved by $33.33 \%$ and $37.83 \%$ respectively.
\end{abstract}

Keywords: Eggshell, hardness, tensile strength, stirring current, matrix pouring temperature

\section{Introduction}

Waste eggshells of about 20,000 tones every year is produced in India $^{1}$. Waste eggshell produces environment pollution around the residential area. Utilization of waste product in manufacturing tends to the green manufacturing approach ${ }^{2}$. Common industrial waste like groundnut shell, human body skelton or bones of animal, fly ash, waste eggshell, bamboo leaf etc. are used as a reinforcement material ${ }^{3)}$. Various attemts were made to develop the composite material using these wastes ${ }^{4}$.

Toro et al. ${ }^{5}$ evaluated the influence of eggshells filler on mechanical characteristics of polypropylene composite. Tensile strength of the prepared specimen was investigated. Noteworthy enhancement in the Young's modulus (E) was found. Boronat et al. ${ }^{\text {) }}$ developed a bio-based composite of polyethylene with eggshells as reinforcement content. In this study, thermal, mechanical, and rheological ware carried out. It was observed that due to the addition of eggshells as a filler degradation temperature showed a proportional effect. Owing to reinforcement mechanical properties were improved. Hassan et al. ${ }^{7}$ highlighted the influence of eggshells content on microstructural and mechanical properties of $\mathrm{Al}-\mathrm{Cu}-\mathrm{Mg}$ based composite. Results illustrated that the mechanical characteristics of fabricated composites were improved.

Influence of eggshells and $\mathrm{SiC}$ content on stir casted Al $6061 / \mathrm{SiC}$ composite was done by Verma et al. ${ }^{8)}$. Reinforcement of 5-8 wt.\% of eggshell had improved yield strength and compressive strength of $\mathrm{Al} 6061 / \mathrm{SiC}$ composite. Eggshell particles reinforced with $\mathrm{Al} / \mathrm{Si}$ composite were mechanical tested by Malik et al. ${ }^{9}$. Addition up to $10 \mathrm{wt} \%$ of eggshell had improved compressive strength and impact energy of the composite. Polypropylene/Eggshell composite was mechanically tested by Lyer et al. ${ }^{10)}$. Young modulus and yield strength was increased.

From literature survey, it can be observed that due to reinforcement of ceramic particle like $\mathrm{SiC}, \mathrm{Al}_{2} \mathrm{O}_{3}, \mathrm{TiC}$, $\mathrm{B}_{4} \mathrm{C}$, and $\mathrm{TiB}_{2}$ mechanical properties of AA 2014 alloy had improved ${ }^{11)}$. Fig 1 shows the waste eggshell source from Poultry - Dutch Meat \& Feed Centre - DMFC Dutch Meat \& Feed Centre - DMFC. This shows that soil pollution was created from the waste eggshell ${ }^{12)}$. These eggshells destroy a large portion of land ${ }^{13)}$. Due to utilization of waste material in the development of new 
composite soil pollution can be reduced ${ }^{14)}$.

Through literature survey, it can be concluded that, very few researchers have used uncarbonized eggshell powder as reinforcement in fabricating the aluminium based composite material by stir casting process using RSM. In this present study, process parameters of stir casting process were optimized by considering hardness as a response factor. The process parameters played a vital role in the development of composite through EMS. Uncarbonized eggshell weight percentage, stirring time, preheat temperature, stirring current and matrix pouring temperature were the selected process parameters. In this research article, the waste uncarbonized eggshell powder was used as reinforcement. The originality of this experiment lie in the fact that only few research has been carried out to utilize west eggshell for development of new composite material in the archival literature. In this experiment, influence of eggshell power on the hardness of AA 2014/eggshell composite prepared by stir casting method was evaluated.

\section{Materials and Methodology}

\subsection{AA 2014 taken as matrix material}

In this experiment, AA 2014 aluminum alloy was taken as matrix material. Nowadays, AA 2014 alloy is used in automotive and aerospace industries due to its superior mechanical properties and light weight. The chemical compositions of AA 2014 alloy are illustrated in Table $1^{15)}$. Table 2 demonstrates the mechanical properties of base metal ${ }^{15)}$.

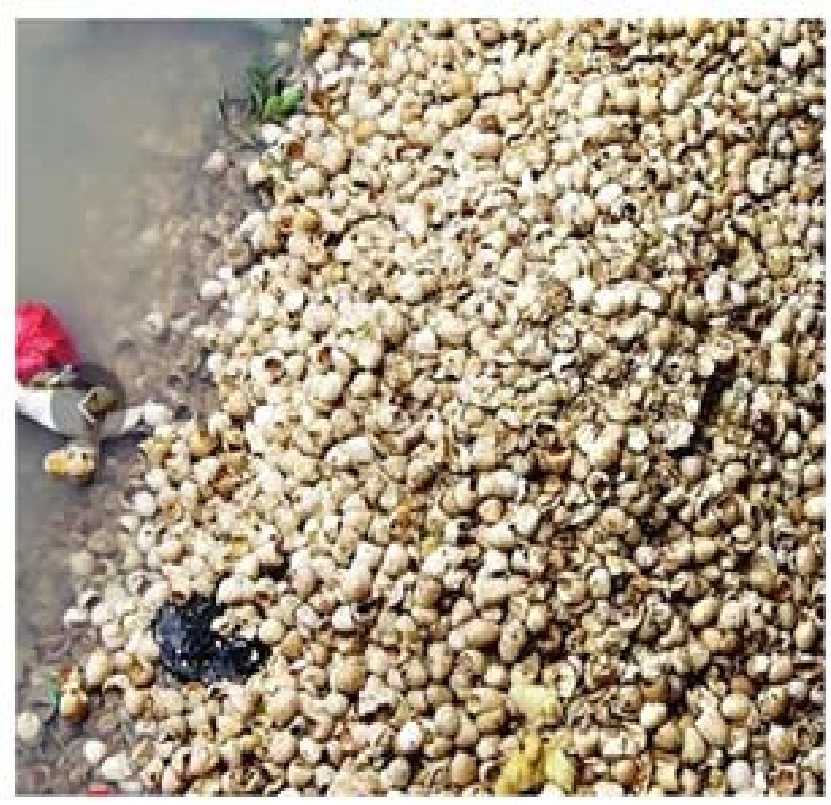

Fig 1: Waste Eggshell creating soil pollution
Table 1: Configuration of Alloy AA 2014 (wt. \%) ${ }^{15)}$

\begin{tabular}{|c|c|c|}
\hline S. No. & Constituents & Wt.-\% \\
\hline 1 & $\mathrm{Cu}$ & $3.89-4.99$ \\
\hline 2 & $\mathrm{Si}$ & $0.49-0.89$ \\
\hline 3 & $\mathrm{Fe}$ & 0.5 \\
\hline 4 & $\mathrm{Zn}$ & 0.25 \\
\hline 5 & $\mathrm{Cr}$ & 0.9 \\
\hline 6 & $\mathrm{Ni}$ & 0.9 \\
\hline 7 & $\mathrm{Mg}$ & $0.2-0.8$ \\
\hline 8 & $\mathrm{Ti}$ & 0.2 \\
\hline 9 & $\mathrm{Mn}$ & $0.4-1.2$ \\
\hline
\end{tabular}

Table 2: Mechanical Characteristics of Alloy AA 2014 ${ }^{15)}$

\begin{tabular}{|l|l|l|}
\hline S. No. & Characteristics & Standards \\
\hline 1 & Toughness $\left(\mathrm{J} / \mathrm{m}^{-3}\right)$ & about 12 \\
\hline 2 & Theoretical density $\left(\mathrm{g} / \mathrm{cm}^{3}\right)$ & 2.79 \\
\hline 3 & Brinell hardness $(\mathrm{BHN})$ & about 60 \\
\hline 4 & Tensile Strength $(\mathrm{MPa})$ & about 185 \\
\hline
\end{tabular}

\subsection{Uncarbonized eggshell as reinforcement}

In this study, waste eggshell powder was used as reinforcing content in aluminium alloy. It consist about 94 wt. \% of calcium carbonate with some impurities as major composition ${ }^{16)}$. Waste eggshells collected from city disposal area were cleaned with water. After that eggshells were sundried for 96-122 hours to eliminate the moisture content ${ }^{17)}$. Eggshells powder was prepared through ball milling process. Ball milled eggshells powder was further pass through multi sieves to obtained desired range of eggshell powder ${ }^{18)}$.

\subsection{Preparation of Composite}

EMS technique was used to prepare AA 2014/uncarbonized eggshell composite. Fig 2 shows the layout of stir casting technique. RSM was employed for conduction of experiment. Owing to the uncertainty of experimental results, three samples were papered for each experiment groups. Total numbers of 78 specimens were prepared and the average values of three samples were selected for the analysis of response. Prepared eggshell reinforced aluminium based composite material in mushy zone. Prepared composite was removed after the solidification form mould. Machining of all the samples were carried out for the different testing as per the ASTM standard ${ }^{20}$. Table No. 3 shows the experimental plan to conduct experiments by EMS process to develop the composite materia 
Table 3: Design matrix Table for hardness

\begin{tabular}{|c|c|c|c|c|c|c|c|}
\hline Std order & Run & $\begin{array}{c}\text { A: } \\
\text { Preheat temperature } \\
\text { of uncarbonized } \\
\text { eggshell powder } \\
\left({ }^{\circ} \mathrm{C}\right)\end{array}$ & $\begin{array}{c}\text { B: } \\
\text { Measured } \\
\text { electromagnetic } \\
\text { stirring current } \\
\text { (Ampere) }\end{array}$ & $\begin{array}{c}\mathrm{C}: \\
\text { Measured } \\
\text { electromag } \\
\text { netic } \\
\text { stirring } \\
\text { time (s) }\end{array}$ & $\begin{array}{l}\text { D: } \\
\text { Matrix pouring } \\
\text { temperature in } \\
\text { crucible after } \\
\text { melting in } \\
\text { furnace }\left({ }^{\circ} \mathrm{C}\right)\end{array}$ & $\begin{array}{c}\text { E: } \\
\text { Uncarbonized } \\
\text { eggshell } \\
\text { weight } \\
\text { percent (\%) }\end{array}$ & $\begin{array}{c}\text { Hardness } \\
(\mathrm{BHN})\end{array}$ \\
\hline 13 & 1 & 600 & 9 & 120 & 800 & 16.6058 & 87.3 \\
\hline 19 & 2 & 600 & 9 & 120 & 800 & 7.5 & 79.71 \\
\hline 9 & 3 & 400 & 6 & 60 & 700 & 2.5 & 69.3 \\
\hline 18 & 4 & 600 & 9 & 229.2696 & 800 & 7.5 & 81.96 \\
\hline 16 & 5 & 400 & 12 & 60 & 900 & 12.5 & 82.2 \\
\hline 11 & 6 & 800 & 6 & 180 & 900 & 2.5 & 71.4 \\
\hline 7 & 7 & 800 & 6 & 180 & 700 & 12.5 & 85.5 \\
\hline 6 & 8 & 400 & 12 & 180 & 900 & 2.5 & 74.7 \\
\hline 8 & 9 & 600 & 9 & 10.73038 & 800 & 7.5 & 79.14 \\
\hline 14 & 10 & 800 & 12 & 60 & 700 & 12.5 & 85.8 \\
\hline 17 & 11 & 600 & 9 & 120 & 800 & 7.5 & 79.575 \\
\hline 26 & 12 & 600 & 9 & 120 & 982.116 & 7.5 & 76.68 \\
\hline 5 & 13 & 600 & 9 & 120 & 800 & 7.5 & 79.725 \\
\hline 3 & 14 & 400 & 12 & 180 & 700 & 12.5 & 85.5 \\
\hline 21 & 15 & 600 & 9 & 120 & 800 & 0 & 69.39 \\
\hline 10 & 16 & 600 & 3.536519 & 120 & 800 & 7.5 & 79.5 \\
\hline 23 & 17 & 600 & 9 & 120 & 617.884 & 7.5 & 80.25 \\
\hline 1 & 18 & 800 & 12 & 180 & 700 & 2.5 & 74.25 \\
\hline 12 & 19 & 800 & 12 & 60 & 900 & 2.5 & 71.25 \\
\hline 25 & 20 & 600 & 9 & 120 & 800 & 7.5 & 79.62 \\
\hline 20 & 21 & 800 & 6 & 60 & 900 & 12.5 & 82.5 \\
\hline 22 & 22 & 600 & 14.46348 & 120 & 800 & 7.5 & 81 \\
\hline 2 & 23 & 964.2321 & 9 & 120 & 800 & 7.5 & 76.2 \\
\hline 4 & 24 & 600 & 9 & 120 & 800 & 7.5 & 79.68 \\
\hline 15 & 25 & 400 & 6 & 180 & 900 & 12.5 & 83.1 \\
\hline 24 & 26 & 235.7679 & 9 & 120 & 800 & 7.5 & 74.1 \\
\hline
\end{tabular}




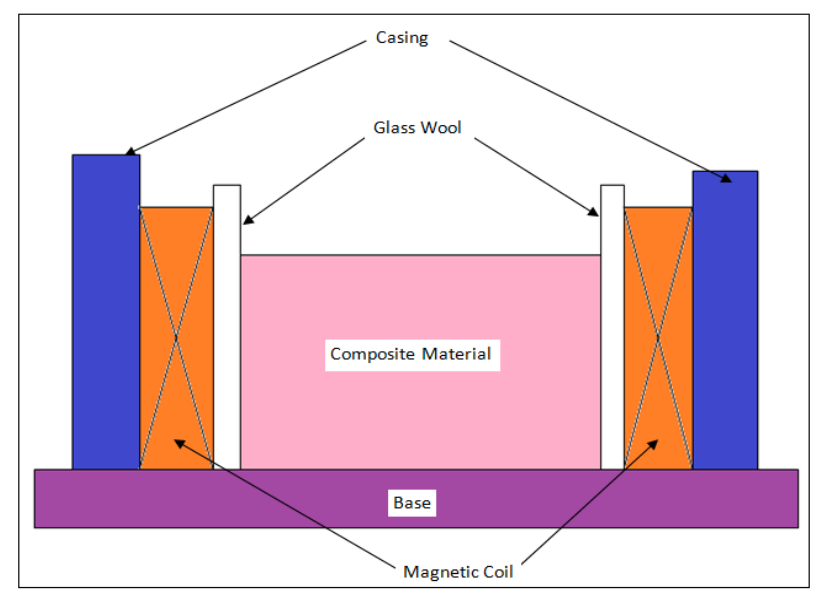

Fig 2: Line diagram of EMS set-up

\section{Results and Discussion}

Waste material as reinforcement material was utilized in this study ${ }^{19)}$. Table 3 shows the measured average value of hardness for each experiment groups. Design of experiment (DOE) software was used to conduct the experiment as shown in Table 3. For checking the adequacy of the developed model, F-test was performed. The next subsection will provide the details of the developed model and influence of EMS parameters on hardness.

\subsection{Mathematical Modelling for Hardness}

A regression model was developed to evaluate the hardness of fabricated composite through the EMS. Table 4 shows the ANOVA of the quadratic regression model and impact of individual EMS parameters. The model F-value of equation 1 was greater than F-tabulated value, which implies that model is statistically correct and can be used for the forecasting of hardness of AA2014/ uncarbonized eggshell composite corresponding to given EMS process parameters, within the experimental domain. There is only $0.01 \%$ chance for the model to fail due to the uncertainty of results ${ }^{21)}$. The probability value (p-value) of all the selected EMS parameters was less than 0.5, which implies that model is fit within the confidence interval of $95^{22}$. The value of $\mathrm{R}^{2}$ was 0.976355 and Adj R-Squared was 0.999711 closes to each other and also closed to 1 . It indicates that the model was significant ${ }^{23)}$.

Hardness $=-1.78294+0.10996 \times \mathrm{A}+1.05620 \times \mathrm{B}+$ $0.10171 \times \mathrm{C}+0.085328 \times \mathrm{D}+0.39226 \times \mathrm{E}-3.44586 \mathrm{x}$ $10^{-005} \times \mathrm{A}^{2}+0.017707 \times \mathrm{B}^{2}+6.93938 \times \mathrm{E}^{-005} \times \mathrm{C}^{2}-$ $3.78834 \times 10^{-005} \mathrm{x} \mathrm{D}^{2}-0.016601 \times \mathrm{E}^{2}-1.47819 \times 10^{-003} \mathrm{x}$ A x B $-1.07235 \times 10^{-004} \times$ A $\times$ C $-5.16222 \times 10^{-005} \times$ A x D $+2.32718 \times 10^{-004} \times$ A x E $-1.65049 \times 10^{-003}$ x B x C$3.92376 \times 10^{-004} \times \mathrm{B} \times \mathrm{D}+0.021497 \times \quad \mathrm{B} \times \mathrm{E}-3.62699$ x $10^{-005} \times \mathrm{C} \times \mathrm{D}+3.66805 \times 10^{-004} \times \mathrm{C} \times \mathrm{E}+5.78835 \mathrm{x}$

$10^{-004} \times \mathrm{D} \times \mathrm{E}$

\subsection{Influence of EMS on hardness}

Particular EMS process parameters i.e. Uncarbonized eggshell weight percentage, stirring time, stirring current, preheat temperature and matrix pouring temperature have influenced the hardness of uncarbonized reinforced aluminium based composite material. The effects of each EMS parameters on hardness are given below ${ }^{24)}$.

\subsubsection{Preheat Temperature Effect on Hardness of Composite}

Fig 3 illustrates the influence of uncarbonized eggshell powder preheat temperature on hardness. Results showed that increased eggshell powder content at preheat temperature up-to $600^{\circ} \mathrm{C}$ had increased the hardness of the composite. However, beyond the $600^{\circ} \mathrm{C}$ of preheat temperature, hardness began to decrease. Reinforcement preheat temperature shows an important role in the enhancement of hardness. Due to an unwarranted preheating of eggshell powder, results in illusions which results lowering the hardness.

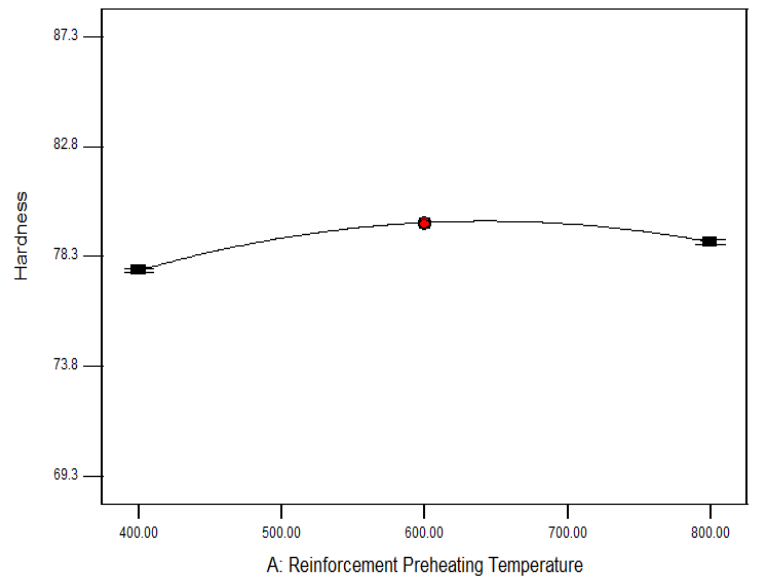

Fig 3: Effect of Preheat Temperature on Hardness of Composite

\subsubsection{Stirring Current Effect on Hardness of AA 2014/eggshell Composite}

Figure 4 shows the influence of stirring current on the hardness of composite material. Experimental results showed that hardness is continuously increases by increasing the stirring current. Stirring current has inclined the hardness of AA 2014/uncarbonized eggshell composite. It can be observed from Fig. 4 that maximum hardness was achieved at $12 \mathrm{~A}$ of stirring current. 


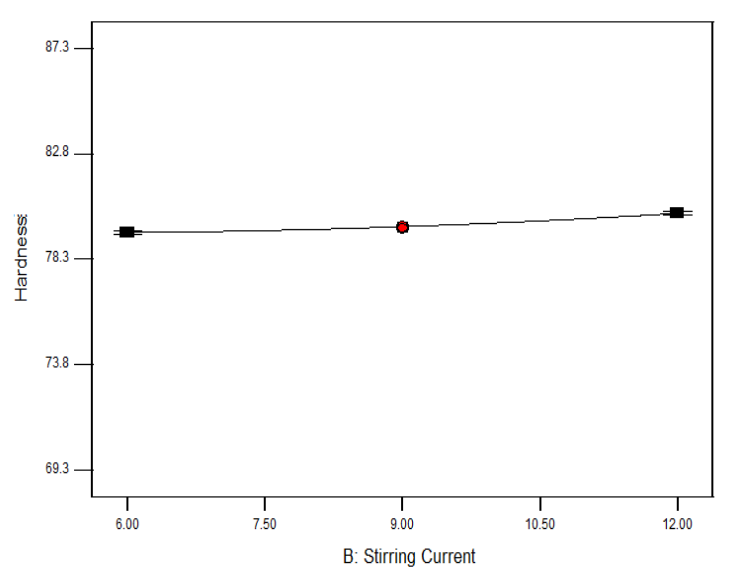

Fig 4: Influence of Stirring Current on Hardness of Composite

\subsubsection{Stirring Time Effect on Hardness of AA 2014/eggshell Composite}

Graph between stirring time and hardness can be observed from Fig. 5. It was found that hardness was continuously increased by increasing the stirring time of electromagnetic stir casting process. In the selected range of process parameters, it was observed that maximum hardness was achieved at 3 minutes of stirring time.

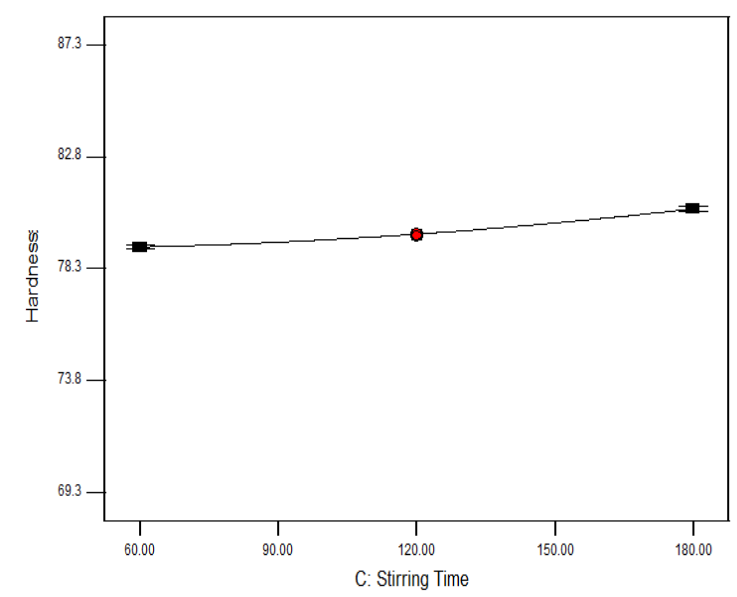

Fig 5: Influence of Stirring Time on Hardness of AA 2014/eggshell Composite.

\subsubsection{Influence of Matrix Pouring Temperature on Hardness of AA 2014/eggshell Composite}

Fig. 6 shows the effect of matrix pouring temperature on the hardness of composite. Hardness of composite is continuously decreases by increasing the matrix pouring temperature in the selected range of process parameters. Due to the poor interfacial bond between matrix material and reinforcement material hardness decreased at higher matrix pouring temperature. It can be concluded that maximum hardness can be achieved at $700^{\circ} \mathrm{C}$ (in the selected range of process parameters)

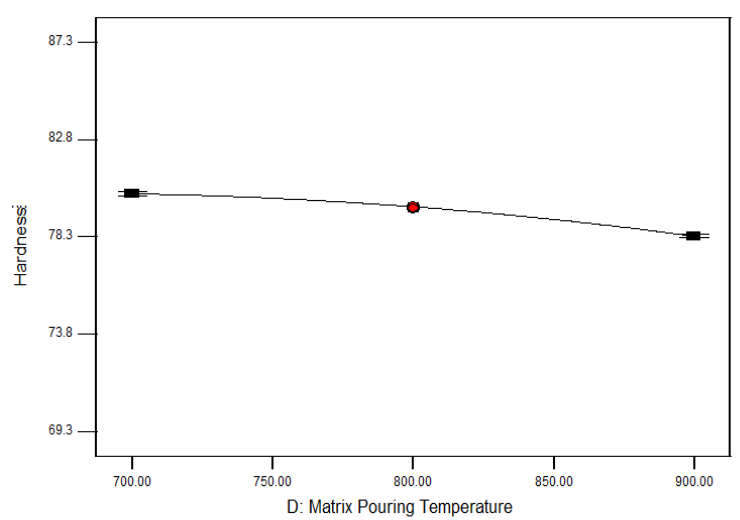

Fig 6: Influence of Matrix Pouring Temperature on Hardness of Composite

\subsubsection{Influence of reinforcement of Eggshell Powder weight percent on Hardness of $A A$ 2014/eggshell Composite}

Fig. 7 shows the influence of eggshell reinforcement weight percent on the hardness of composite. It can be clearly seen hardness was maximum at $12.5 \mathrm{wt} \%$ of uncarbonized eggshell reinforcement. On increase of eggshell wt \% hardness was increased. Hardness of composite was increased due to the occurrence of hard phases $\left(\mathrm{CaCO}_{3}\right)$ in eggshell powder

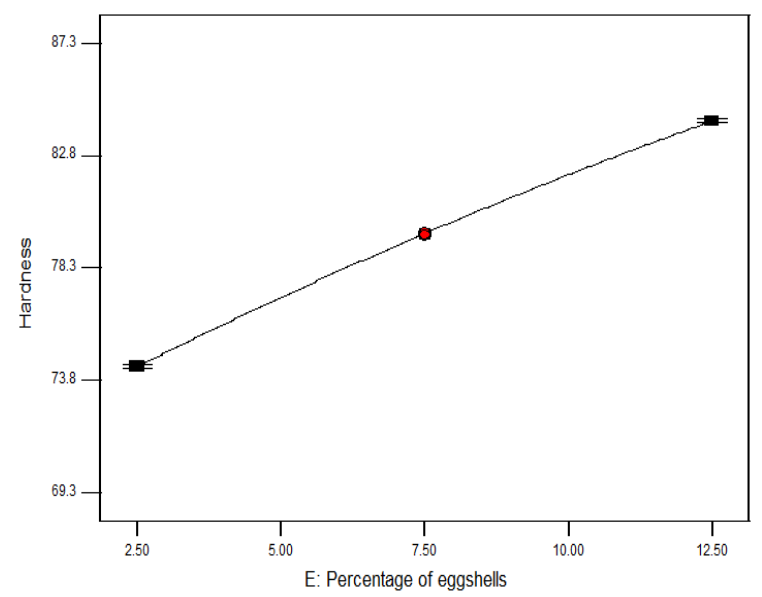

Fig 7: Influence of reinforcement of Eggshell Powder Weight Percent on Hardness of AA 2014/eggshell Composite

\subsubsection{D-Interaction of EMS parameters on Hardness}

Fig. 8 shows the 3D interaction of EMS parameters on hardness. It can be observed from Figures 8 that, with increasing the reinforcement preheat temperature up to center limit and stirring current, the hardness of composite material also increases. In the same way, interaction effect of others parameters with hardness can be descried. 
Table 4: ANOVA Table for Hardness Composite

\begin{tabular}{|c|c|c|c|c|c|c|}
\hline Source & Sum of Squares & DF & $\begin{array}{l}\text { Mean } \\
\text { Square }\end{array}$ & F Value & Prob $>$ F & \\
\hline Model & 637.4047 & 20 & 31.87024 & 4328.76 & $<0.0001$ & significant \\
\hline A & 2.205 & 1 & 2.205 & 299.50 & $<0.0001$ & \\
\hline $\mathrm{B}$ & 1.125 & 1 & 1.125 & 152.8 & $<0.0001$ & \\
\hline $\mathrm{C}$ & 3.9762 & 1 & 3.9762 & 540 & $<0.0001$ & \\
\hline $\mathrm{D}$ & 6.37245 & 1 & 6.37245 & 865.5 & $<0.0001$ & \\
\hline $\mathrm{E}$ & 160.3841 & 1 & 160.3841 & 21784 & $<0.0001$ & \\
\hline A2 & 39.37428 & 1 & 39.37428 & 5348 & $<0.0001$ & \\
\hline B2 & 0.526355 & 1 & 0.526355 & 71.50 & 0.0004 & \\
\hline $\mathrm{C} 2$ & 1.293431 & 1 & 1.293431 & 175.68 & $<0.0001$ & \\
\hline D2 & 2.974368 & 1 & 2.974368 & 404 & $<0.0001$ & \\
\hline E2 & 3.569646 & 1 & 3.569646 & 484.85 & $<0.0001$ & \\
\hline $\mathrm{AB}$ & 2.40404 & 1 & 2.40404 & 326.53 & $<0.0001$ & \\
\hline $\mathrm{AC}$ & 5.060749 & 1 & 5.060749 & 687.37 & $<0.0001$ & \\
\hline $\mathrm{AD}$ & 3.257707 & 1 & 3.257707 & 442.48 & $<0.0001$ & \\
\hline $\mathrm{AE}$ & 0.165515 & 1 & 0.165515 & 22.48 & 0.0051 & \\
\hline $\mathrm{BC}$ & 0.269745 & 1 & 0.269745 & 36.64 & 0.0018 & \\
\hline $\mathrm{BD}$ & 0.042348 & 1 & 0.042348 & 5.76 & 0.0618 & \\
\hline $\mathrm{BE}$ & 0.31776 & 1 & 0.31776 & 43 & 0.0012 & \\
\hline $\mathrm{CD}$ & 0.144735 & 1 & 0.144735 & 19.6 & 0.0068 & \\
\hline $\mathrm{CE}$ & 0.037008 & 1 & 0.037008 & 5.0 & 0.0750 & \\
\hline $\mathrm{DE}$ & 0.255994 & 1 & 0.255994 & 34.7 & 0.0020 & \\
\hline Residual & 0.036812 & 5 & 0.007362 & & & \\
\hline Lack of Fit & 0.020882 & 1 & 0.020882 & 5.24 & 0.08 & not significant \\
\hline Pure Error & 0.01593 & 4 & 0.003982 & & & \\
\hline Cor Total & 637.4415 & 25 & & & & \\
\hline Std. Dev. & 0.085804712 & $\mathrm{R}^{2}$ & 0.999942 & & & \\
\hline Mean & 78.82038462 & R2-Adj & 0.999711 & & & \\
\hline C.V. & 0.108861067 & $\mathrm{R}^{2}$ - Pred & 0.976355 & & & \\
\hline PRESS & 15.07205929 & Adeq Precision & 232.4501 & & & \\
\hline
\end{tabular}




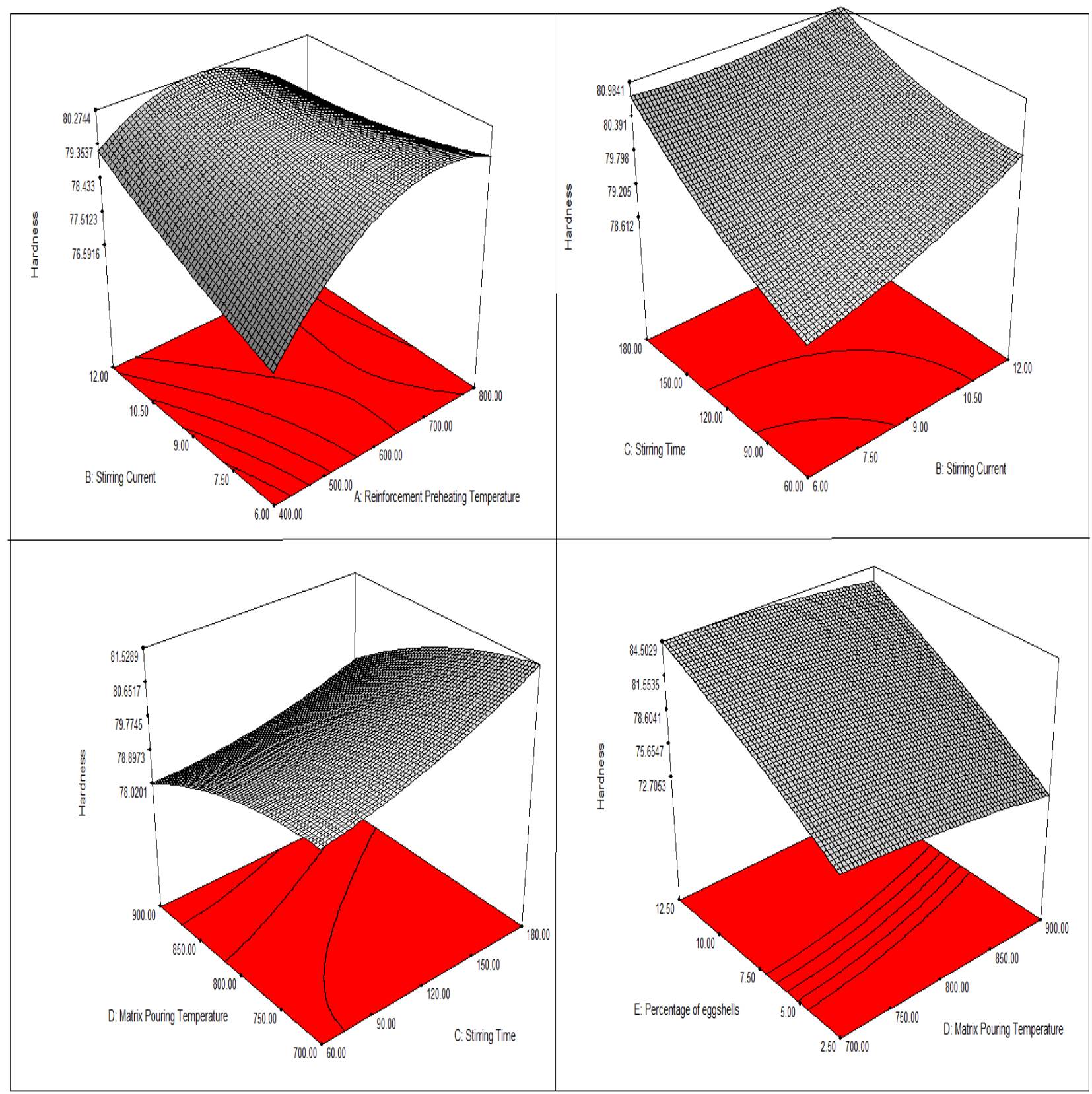

Fig 8: 3D-Interaction of EMS parameters on Hardness

\subsection{Confirmation Experiment}

A confirmation test was performed to validate the developed regression model. The optimum level of process parameters were found to be stirring current of $12 \mathrm{~A}$, matrix pouring temperature of $700^{\circ} \mathrm{C}$, reinforcement preheat temperature of $600{ }^{\circ} \mathrm{C}$, stirring time of 3 minutes and reinforcement wt. \% of 12.5 . Owing to uncertainty of results three samples were fabricated at optimum level of process parameter and average value of hardness of three samples was compared with the model value ${ }^{25}$. The average value of three samples of hardness was $86.4865 \mathrm{BHN}$. At the optimum level of process parameter tensile strength was also evaluated. The average value of tensile strength of three samples was found to be $255 \mathrm{MPa}$. However, ductility and toughness of composites were reduced as compared to the base matrix material.

Optical Microscopy test was conducted to examine the distribution of eggshells particle in the fabricated composite. Study showed that at optimum level of process parameters uniform distribution of eggshells powder was observed. Fig.10 shows the presence of eggshells in the fabricated composite at optimum level of process parameter. 


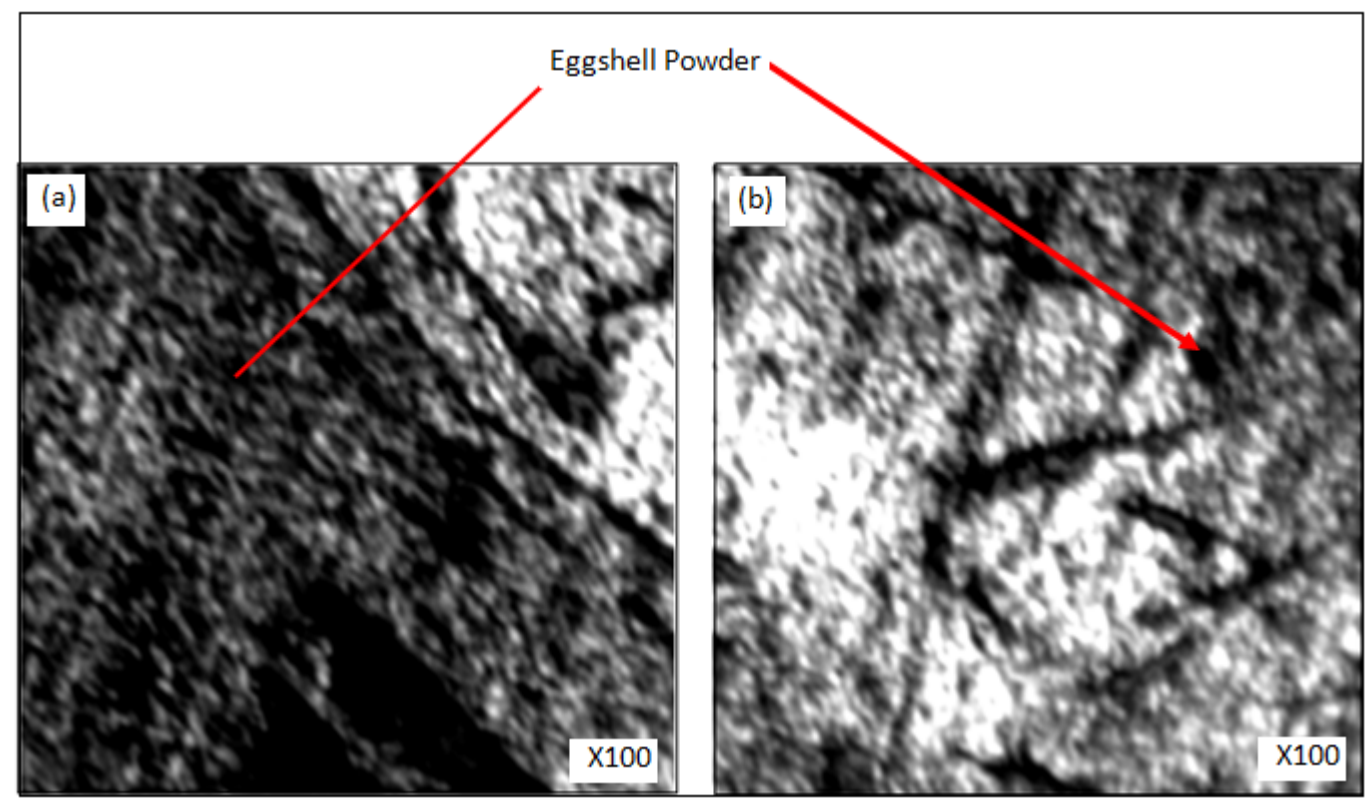

Fig 10: Microstructure of AA2014/12.5 wt. \% uncarbonized eggshell composite

\subsection{Comparison of result with previous experimental results}

Table 5 shows the comparative study of effect of reinforcement of eggshell particles on mechanical properties of aluminium alloys. It was observed that due to reinforcement of eggshell particle mechanical properties tensile strength and hardness were improved. However, other mechanical properties i.e. toughness and ductility were decreased. Dwivedi et.a ${ }^{15)}$ have conducted experiment to find out optimum electromagnetic stir casting process parameter for response factor tensile strength and conducted other mechanical properties at corresponding optimum level of process parameters. The optimum level of process parameters are shown in Table 5. In this study, effect of reinforcement of uncarbonized eggshell on mechanical properties of AA2014 was investigated. Mechanical properties hardness was selected as a response variable. At optimum level of process parameters tensile strength was also calculated. Dwivedi et.al ${ }^{15)}$ results showed that tensile strength was improved at optimum electromagnetic stir casting parameter about $51.35 \%$ with respect to base alloy, when tensile strength was considered as response. However, hardness was also increased about $41.66 \%$.

In the present study, hardness was improved about $44.73 \%$ with respect to base alloy at optimum EMS process parameters when hardness was considered as response. Tensile strength at corresponding EMS process parameters was increased about $37.83 \%$. From these results, it can be concluded that the optimum level of process parameters for tensile strength and hardness were different as shown in Table 5. Sometimes, tensile strength is more important factor in the selection of material. In this case, composite material should be developed at the optimum combination of EMS process parameters by considering tensile strength as response. In certain applications, where relative motion between surfaces of the components exists due to which wear and tear occur. To minimize surface wear, hard materials are required without significant changes in tensile strength of material. Keeping these facts in the mind, in this study, hardness was considered as response. For AA2014/eggshell composite can be forecasted by using the suggested regression model (equation 1).

Hassan et al. ${ }^{7}$ has conducted experimental study to investigate the effect of carbonized eggshell as reinforcement on tensile strength and hardness of Al-Cu-Mg alloy. Stir casting technique was used to develop the eggshell reinforced $\mathrm{Al}-\mathrm{Cu}-\mathrm{Mg}$ alloy based composite. Results revealed that tensile strength and hardness of Al-Cu-Mg/12 wt. \% eggshell were improved about $14.28 \%$ and $25.4 \%$ respectively.

Current study was performed on electromagnetic stir casting (EMS) set-up. In this set-up, composite material is mixed by using the magnetic forces developed by electromagnetic field. There is no any stirrer is used to mixed the materials, Hence, probability of porosity occurrence is very low. While, in mechanical stir casting process, external stirrer is used to mix the reinforcement particles in the melted matrix material. In this case, probability of porosity occurrence is very high. Resulting, mechanical properties of composite developed by stir casting process are low as compared to electromagnetic stir casting (EMS). 
Table 5: Comparing Properties of Present Investigation with the Previous Work

\begin{tabular}{|c|c|c|c|c|c|c|c|c|}
\hline S.N & $\begin{array}{l}\text { Author } \\
\text { Name }\end{array}$ & Base Material & $\begin{array}{l}\text { Reinforcem } \\
\text { ent particle }\end{array}$ & $\begin{array}{l}\text { Optimum } \\
\text { process }\end{array}$ & $\begin{array}{l}\text { Response } \\
\text { variable }\end{array}$ & \multicolumn{2}{|c|}{$\begin{array}{l}\text { Mechanical Properties of } \\
\text { composite }\end{array}$} & $\begin{array}{l}\text { Percentage } \\
\text { change }\end{array}$ \\
\hline \multirow[t]{2}{*}{1} & \multirow[t]{2}{*}{$\begin{array}{l}\text { Present } \\
\text { study }\end{array}$} & \multirow[t]{2}{*}{ AA2014 } & \multirow{2}{*}{$\begin{array}{l}\text { Un-carboni } \\
\text { zed } \\
\text { Eggshell }\end{array}$} & \multirow{2}{*}{$\begin{array}{l}\mathrm{SC}=12 \mathrm{~A}, \\
\mathrm{MPT}=700^{\circ} \mathrm{C}, \\
\mathrm{RPT}=600{ }^{\circ} \mathrm{C}, \\
\mathrm{ST}=180 \mathrm{~s} \\
\mathrm{RWT}=12.5 \\
\text { (Electromagneti } \\
\mathrm{c} \text { stir casting) }\end{array}$} & \multirow[t]{2}{*}{ Hardness } & $\begin{array}{l}\text { Tensile } \\
\text { strength }\end{array}$ & $255 \mathrm{MPa}$ & $\begin{array}{l}37.83 \% \\
\text { Increased }\end{array}$ \\
\hline & & & & & & Hardness & $\begin{array}{l}86.84 \\
\text { BHN }\end{array}$ & $\begin{array}{l}44.73 \% \\
\text { Increased }\end{array}$ \\
\hline \multirow[t]{4}{*}{2} & \multirow{4}{*}{$\begin{array}{l}\text { Dwivedi } \\
\text { et.al }{ }^{15)}\end{array}$} & \multirow[t]{4}{*}{ AA2014 } & \multirow{4}{*}{$\begin{array}{l}\text { Un-carboni } \\
\text { zed } \\
\text { Eggshell }\end{array}$} & \multirow{4}{*}{$\begin{array}{l}\mathrm{SC}=12 \mathrm{~A}, \\
\mathrm{MPT}=764.96^{\circ} \mathrm{C}, \\
\mathrm{RPT}= \\
608.28^{\circ} \mathrm{C}, \\
\mathrm{ST}=178.38 \mathrm{~s} \\
\mathrm{RWT}=12.5 \\
\text { (Electromagneti } \\
\text { c stir casting) }\end{array}$} & \multirow[t]{4}{*}{$\begin{array}{l}\text { Tensile } \\
\text { strength }\end{array}$} & $\begin{array}{l}\text { Tensile } \\
\text { strength }\end{array}$ & $280 \mathrm{MPa}$ & $\begin{array}{l}51.35 \% \\
\text { increased }\end{array}$ \\
\hline & & & & & & Hardness & $85 \mathrm{BHN}$ & $\begin{array}{l}41.66 \% \\
\text { Increased }\end{array}$ \\
\hline & & & & & & Toughness & Joule & $\begin{array}{l}20.83 \% \\
\text { decreased }\end{array}$ \\
\hline & & & & & & Ductility & $\begin{array}{c}\% \\
\text { Elongation }\end{array}$ & $\begin{array}{l}9.09 \% \\
\text { decreased }\end{array}$ \\
\hline \multirow[t]{2}{*}{3} & \multirow[t]{2}{*}{$\begin{array}{l}\text { Hassan } \\
\text { et al. }{ }^{7)}\end{array}$} & \multirow{2}{*}{$\begin{array}{l}\mathrm{Al}-\mathrm{Cu}-\mathrm{Mg} \\
\text { alloy } \\
\text { (Tensile } \\
\text { Strength } \\
=98.28 \mathrm{MPa} \text {, } \\
\text { Hardness = } \\
\text { 59.12 HRF) }\end{array}$} & \multirow[t]{2}{*}{$\begin{array}{l}\text { Carbonize } \\
\text { d eggshell }\end{array}$} & \multirow[t]{2}{*}{$\begin{array}{l}\mathrm{ST}=900 \mathrm{~s} \\
\mathrm{RWT}=12\end{array}$} & \multirow[t]{2}{*}{ - } & $\begin{array}{l}\text { Tensile } \\
\text { strength }\end{array}$ & $\begin{array}{l}112.84 \\
\mathrm{MPa}\end{array}$ & $\begin{array}{l}14.28 \% \\
\text { Increased }\end{array}$ \\
\hline & & & & & & Hardness & $\begin{array}{l}74.17 \\
\text { HRF }\end{array}$ & $\begin{array}{l}25.4 \% \\
\text { Increased }\end{array}$ \\
\hline
\end{tabular}

\section{Conclusions}

In this study, AA 2014/eggshell based composite material was effectively prepared by using uncarbonized eggshell powder as reinforcement content via EMS. EMS parameters were optimized by considering hardness as response. Optimum process parameters of EMS was found to be stirring current of $12 \mathrm{~A}$, matrix pouring temperature of $700^{\circ} \mathrm{C}$, reinforcement preheat temperature of $600{ }^{\circ} \mathrm{C}$, stir time of 3 minutes and reinforcement weight percentage of 12.5. Hardness and tensile strength of AA 2014/eggshell composite was observed at optimum reinforcement parameters. Hardness and tensile strength were enhanced by 33\%, $37.83 \%$ respectively as compared to base metal.

\section{References}

1) S. Milind, V. Ramanarayanan; "Design and Analysis of a Linear Type Electromagnetic Stirrer"; IAS IEEE; (2004); pp. 188-194.

2) Guanglei Zhu, Jun $\mathrm{Xu}$, Zhifeng Zhang, YuelongBai, Likai Shi; "Annular Electromagnetic Stirring a New Method for the Production of Semi-Solid A357 Aluminum Alloy Slurry"; Acta Metallurgical Sinica (Engl. Letters); Vol. 22 (2009); pp. 408-414.

3) Lamiaa M. Radwan, M. M. Fathi, A. Galal and A. Zein El-Dein; "Mechanical and Ultrastructural
Properties of Eggshell in Two Egyptian Native Breeds of Chicken"; International Journal of Poultry Science; Vol. 9 (2010); pp. 77-81.

4) Manish Maurya, Sudhir Kumar, and VivekBajpai, Assessment of the mechanical properties of aluminium metal matrix composite: A review, Journal of Reinforced Plastics and Composites (2019), 38(6):267-298.

5) P. Toro , R. Q, M. Y. Pedram, J. L.Arias; "Eggshell, a new bio-filler for polypropylene composites"; Materials Letters; Vol.61 (2007); pp.4347-4350.

6) T. Boronat, V. Fombuena, D. Garcia-Sanoguera, L. Sanchez-Nacher, R. Balart; "Development of a biocomposite based on green polyethylene biopolymer and eggshell"; Materials and Design; Vol68, (2015);pp.177-185.

7) S.B. Hassan , V.S. Aigbodion; "Effects of eggshell on the microstructures and properties of $\mathrm{Al}-\mathrm{Cu}-\mathrm{Mg}$ /eggshell particulate composites"; Journal of King Saud University - Engineering Sciences; Vol. 27, Issue 1, (2015); pp. 49-56.

8) V. Verma, Nishant, M. Gill; "Effects of waste eggshells and silicon carbide addition in the synthesis of aluminium alloy 6061 hybrid green metal matrix composite" International Research Journal of Engineering and Technology (IRJET); 
Vol.5 (2018); pp.1413-1419..

9) Anjali, R. Malik, S. Bhandari, A. Pant, A. Saxena, Seema, N. Kumar, N. Chotrani, D. Gunwant, P. L. Sah; "Fabrication and Mechanical Testing of Egg Shell Particles Reinforced Al-Si Composites"; International Journal of Mathematical, Engineering and Management Sciences; Vol. 2, (2017)pp. 53-62.

10) Krishnan A. Iyer, John M. Torkelson; "Green composites of polypropylene and eggshell: Effective biofiller size reduction and dispersion by single-step processing with solid-state shear pulverization"; Composites Science and Technology,Vol. 102 (2014) pp. 152-160.

11) A. A. Iqbal, Y. Arai, W. Araki; "Effect of Hybrid Reinforcement on Crack Initiation and Early Propagation Mechanisms in Cast Metal Matrix Composites During Low Cycle Fatigue"; Materials \& Design; Vol. 45 (2013); pp. 241-252.

12) A. Tarig Hassan, K. Vijay Rangari, K. R. Rana, S. Jeelani; "Sonochemical Effect on Size Reduction of CaCO3 Nano-particles Derived From Waste Eggshells"; UltrasonicsSonochemistry; Vol. 20 (2013); pp.1308-1315.

13) Libor Severa, JiríNemecek, ŠárkaNedomová, JaroslavBuchar; "Determination of Micromechanical Properties of a Hen's Eggshell by Means of Nanoindentation"; Journal of Food Engineering; Vol. 101 (2010); pp. 146-151.

14) Xia Chen, Chengwu Li, Jun Wang, Jia Li, Xiaoyu Luan, Ying Li, RuiXu, Baoxin Wang; "Investigation on Solar Photocatalytic Activity of $\mathrm{TiO} 2$ Loaded Composite: TiO2/Eggshell, $\mathrm{TiO} 2 /$ Clamshell and TiO2/CaCO3"; Materials Letters; Vol. 64 (2010); pp. 1437-1440.

15) S.P.Dwivedi, N. K. Maurya, M. Maurya; "Effect of Uncarbonized Eggshell Weight Percentage on Mechanical Properties of Composite Material Developed by Electromagnetic Stir Casting Technique"; Revue des Composites et des Matériaux Avancés; Vol. 29 (2019); pp. 101-107.

16) Sneha Lunge, DilipThakre, Sanjay Kamble, NitinLabhsetwar, SadhanaRayalu; "Alumina Supported Carbon Composite Material with Exceptionally High Defluoridation Property from Eggshell Waste"; Journal of Hazardous Materials; Vol. 237 - 238 (2012); pp. 161- 169.

17) M. C. Yew, N. H. RamliSulong, M. K. Yew, M. A. Amalina, M. R. Johan; "The Formulation and Study of the Thermal Stability and Mechanical Properties of an Acrylic Coating Using Chicken Eggshell as a Novel Bio-filler"; Progress in Organic Coatings; Vol. 76 (2013); pp. 1549- 1555.

18) MunlikaBootklad, KaewtaKaewtatip; "Biodegradation of Thermoplastic Starch/Eggshell Powder Composites"; Carbohydrate Polymers; Vol. 97 (2013); pp. 315-320.

19) EnyKusrini, DijanSupramono, Muhammad
IdrusAlhamid, Saeful Pranata1, Lee D. Wilson, Anwar Usman, "Effect of Polypropylene Plastic Waste as Co-feeding for Production of Pyrolysis Oil from Palm Empty Fruit Bunches", EVERGREEN Joint Journal of Novel Carbon Resource Sciences \& Green Asia Strategy, Vol. 06, (2019), pp.92-97.

20) AzinAhmadi, Mohammad Reza Toroghinejad, Abbas Najafizadeh; "Evaluation of Microstructure and Mechanical Properties of $\mathrm{Al} / \mathrm{Al}_{2} \mathrm{O}_{3} / \mathrm{SiC}$ Hybrid Composite Fabricated by Accumulative Roll Bonding Process"; Materials \& Design; Vol. 53 (2014); pp. 13-19.

21) A. Devaraju, A. Kumar, A. Kumaraswamy, B. Kotiveerachari; "Influence of Reinforcements (SiC and A12O3) and Rotational Speed on Wear and Mechanical Properties of Aluminum Alloy 6061-T6 based Surface Hybrid Composites Produced via Friction Stir Processing"; Materials \& Design; Vol. 51 (2013); pp. 331-341.

22) P. K. Rohatgi, J. K. Kim, N. Gupta, Simon Alaraj, A. Daoud; "Compressive Characteristics of A356/Fly Ash Cenosphere Composites Synthesized by Pressure Infiltration Technique"; Composites: Part A; Vol. 37 (2006); pp. 430-437.

23) N. Natarajan, S. Vijayarangan, I. Rajendran; "Wear Behaviour of A356/25SiCp Aluminium Matrix Composites Sliding Against Automobile Friction Material"; Wear; Vol. 261 (2006); pp. 812-822.

24) T. P .D. Rajan, R. M. Pillai, B. C. Pai, K. G. Satyanarayana, P. K. Rohatgi; "Fabrication and Characterisation of $\mathrm{Al}-7 \mathrm{Si}-0.35 \mathrm{Mg} /$ Fly Ash Metal Matrix Composites Processed by Different Stir Casting Routes"; Composites Science and Technology; Vol. 67 (2007); pp.3369-3377.

25) R. RahmaniFard, F. Akhlaghi; "Effect of Extrusion Temperature on the Microstructure and Porosity of A356-Sicp Composites"; Journal of Materials Processing Technology; Vol. 187-188 (2007); pp. 433-436. 